\title{
Welfare Implications for Dairy Cattle of Modern Technological Advances: (I) Robotic Milking
}

\author{
David Williams* \\ Department of Veterinary Medicine, University of Cambridge CB3 OES, UK
}

Submission: January 27, 2019 ; Published: February 08, 2019

*Corresponding author: David Williams, Department of Veterinary Medicine, University of Cambridge CB3 0ES, UK, Email: dlw33@cam.ac.uk

\begin{abstract}
Automatic milking systems, otherwise, known as robotic milking, have been used in dairy farms more and more over the past two decades. The system gives the cattle the opportunity to decide when they are milked which should be beneficial to their welfare, but potentially separated the farmer from his or her animals, which could be detrimental. Here we look at health and welfare implications of robotic milking, seek to review research undertaken in this area and look to future advances in automatic milking of dairy cattle.
\end{abstract}

\section{Introduction}

The introduction of automatic milking systems (AMS) in the late 1990s revolutionised dairy practice where it was employed. The AMS is comprised of a milking machine, a laser sensor of teat position, a robotic arm to automatically apply and remove the cup to and from the teat and a gate system for controlling cow traffic and is commonly termed robotic milking Figure 1 . The idea of the system is that it allows the cow to decide, within certain limitation discussed later, when to be milked with advantages for the farmer in giving increased milk yields and to the cow in increasing her autonomy, an important factor in optimising cattle welfare. Potential downsides of reducing the interaction between cowman and his or her animals are alleviated by including sensors for mastitis in the form of automatic sensors for blood in milk or increased cell count and for lameness in the form both of automatic assessment of time between milking and use of pedometers for directly assessing cow movement (Figure 2).

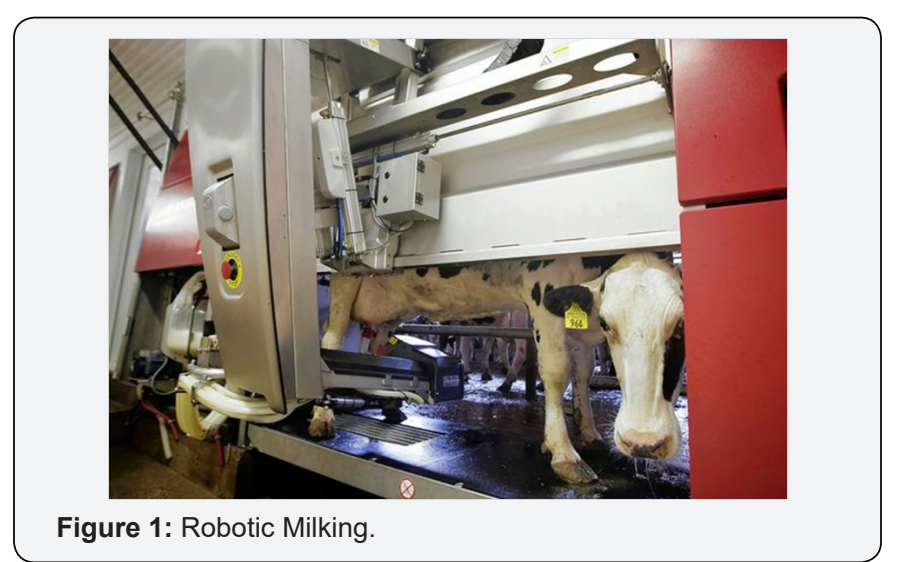

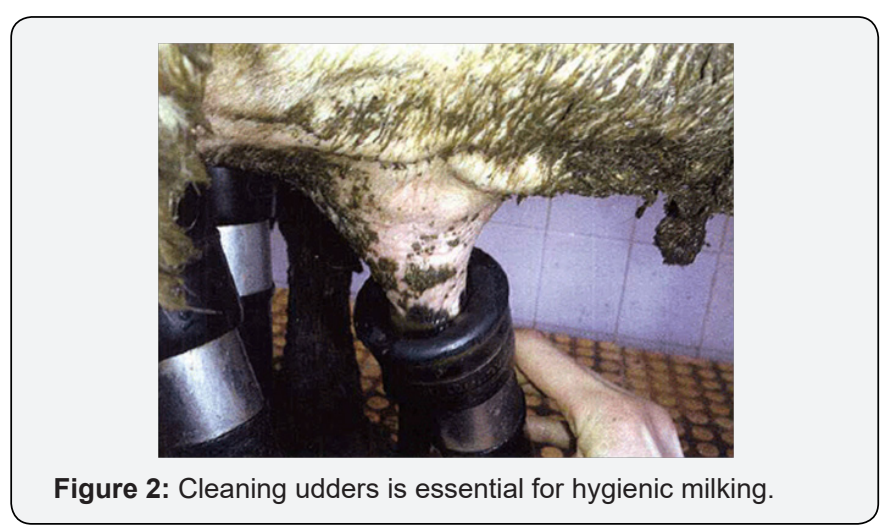

In this review we will discuss the benefits, or otherwise, of robotic milking to dairy cow welfare and ask how use of such systems impact the relationship between farmer and animals, and what indirect effects this has on cattle welfare. It must be said that robotic milking was first introduced in the context of the standard dairy parlour but the automated application of cups to the teats just did not work in the standard parlour where animals are milked in groups twice daily. The robotic systems were then placed in the areas where the cows were accommodated with the idea that each cow would enter the robotic system when it needed to be milked. It turned out that the 'need' to be milked was not enough to entice cows into the milking systems and so food was given at the time of milking. Perhaps the automated milking system was not quite as focussed on cow welfare as had first been thought. We will discuss the degree to which the cow is in control of her life while using an AMS later, given the importance of individual cow autonomy to cow welfare. First though 
we need briefly to outline the welfare issues in conventional dairy systems before comparing different AMS systems and then looking at the research published to date on stress levels in conventional dairy farms and those using AMS.

\section{Welfare Problems in Conventional Dairy Systems}

The three key areas of animal welfare, as proposed by Fraser involve first biological functioning, the physiological state of the animal, natural living, how close the animal is in captivity to its free-living state, and its affective state, how it is feeling [1]. The breeding of dairy cattle for increased milk yield brings several welfare problems from a physiological and disease perspective [2] quite apart from behavioural and affective issues or removing calves from their dams at an early stage and then managing them in a manner that precludes them fulfilling their normal behaviours [3]. The energy and nutrient requirements engendered by the vastly increased milk production in modern dairy cattle places significant burdens on the cow and leads to the problems of diminished reproductive performance, decreased levels of udder health with increased incidence of mastitis [4,5], increased prevalence of lameness both associated with increased standing and musculoskeletal health issues [6] as well as compromise in the animal's ability to eat enough to maintain a nutritional balance when so much energy, protein and calcium are being lost in the litres of milk produced each day.

The cow is, as we would say 'milking off her back' with insufficient resources being put back into her own health. This is the reason why the average number of lactations for a modern dairy cow is now as low as 3 with a recent study showing that the annual herd cull rate for US dairy farms was $36 \%$ and the longevity of dairy cows was approximately 60 months [7]. Can automatic milking allow the cow a better affective existence by giving her more control of her own milk production by allowing her to decide when to be milked? Or does robotic milking increase problems by distancing the cattle from the farmer?

\section{Robotic Milk and Cattle Health}

Having noted the short lifespan of most cattle in today's relatively intensive dairy industry doe an AMS have an impact on this figure? A recent paper on 23 Holstein breed dairy farms in Gallicia, Spain [8] monitored for five years showed that milk yield increased in the move to AMS emergency culling for conditions such as abomasal displacement, postpartum ketoacidosis or accidents reduced while culling for poor production, infertility or lameness increased. It may be that increased culling for low production comes because the AMS allows a better analysis of the cow's performance and so a weaning out, as it were, of sub-optimally performing animals. This would not have an impact on individual animal welfare.

Increased culling because of mastitis in AMS systems may be associated with poorer udder health in the farms using AMS. Most previous studies have noted a decrease in udder health on using robotic milking [9]. Ineffective udder cleaning, generally dirtier udders and inadequate detection of mastitis may be responsible for these defects and previous studies have shown suboptimal udder cleaning in robotic systems [10]. Assessment of bulk milk somatic cell counts and bacterial counts in thirteen farms which moved from conventional milking to an AMS system detected a significantly increased cell count and bacterial contamination in the first year after the transfer but by three years after the introduction of AMS, when farmers had become accumsomed to managing the new equipment, both bulk milk cell count and bacterial count were lower than in the conventional milking system [10]. Figure 1 illustrates the unclean state into which cattle can descend, illustrating the importance of good udder cleaning, not necessarily reached when an automated system is responsible for udder health. On the other hand, in AMS systems sensors can monitor milk quality, cell counts and bacterial contamination. By rapid detection of affected cattle, those individual animals can more promptly be treated and removed from the dairy system until healthy again.

The daily routine of a dairy cow in an AMS dairy is quite different from that in a conventional system. The cow has a relatively low motivation to be milked and so is attracted to the milking robot by provision of concentrates [11]. Lameness may reduce the frequency of cows visiting the milking system with deleterious effects on both their welfare and on the farm's economy. In a study of eight farms $14 \%$ of cattle were lame and in $12 \%$ of these animals lameness was severe [12]. The fact that these cows are living in an environment where their feet are continually in a muddy environment may be significant in such a finding. The fact that the animals are not being examined on a twice daily basis by the stockman in the dairy setting may exacerbate this. The opportunity of automatic assessment of leg health using load sensors, however, gives the prospect of early detection of sole ulcers, infected claws and other foot defects could greatly benefit dairy cattle if widely used $[13,14]$.

A finding of higher culling rates because of infertility in dairy cattle [8] may be associated with the fact that although farmers using a robotic system may have more time to evaluate their herd and the cows' behaviour, they are not actually in the proximity of the cattle as was the case twice daily in the parlour, detecting the changes that indicate oestrous [15]. More important effects on reproduction may occur because with increased milk yield in an automatic system a deeper negative energy balance has a deleterious effect on fertility.

\section{Affective Changes in Cattle Moving to Robotic Systems}

As we noted above the hope is that an automatic milking system would give the cows control over their frequency and timing of milking with advantages to their welfare. But how do cattle cope with a move from a conventional system to AMS? In a study of seventeen healthy cows transitioning to a robotic system heart rate and faecal cortisol was unchanged and the introduction of AMS milking was less stressful than tethering. Within two to four visits the cattle entered the robotic milking system 
voluntarily and in the words of the researchers 'the adaptation to the AMS system was unexpectedly fast' [16]. Initially in the unfamiliar environment oxytocin release and milk let-down was reduced but this soon normalised. A study of stress responses on cattle milking in a conventional and AMS system detected lower maximak plasma adrenaline and noradrenaline concentrations during milking in the AMS animals. No differences were found in the number of steps. Stimulation of the teats gave similar mean oxytocin concentrations but in the AMS-cows this increase in oxytocin levels was more prolonged after milking. AMS animals tended to have higher plasma cortisol concentrations than traditionally milked cows, but the median feacal concentrations of dioxo androstane, a cortisol metabolite were comparable [17].

If we can say that stress levels are comparable between the two systems, does robotic milking, in the words of one article 'recapture the bovine life' [18]? The authors of this paper undertook in depth interviews with farmers and observed them in their dairy farms before using Foucault's concepts of relationships to assess the way a move to robotic milking influences behaviour and lifestyles of both animals and farmers. As they say 'the rhetoric of choice and freedom suggested by manufacturers of robotic milking systems needs some interrogation [18]. They suggest that 'the complex layouts of fences and gates which 'guide', 'force' or 'discipline' cows' movements and intervene with their daily movements' significantly constrain the cows' behaviour and that actually 'the simplistic representations of a bovine subjectivity 'freed' by robotic milking, and more complex processes of bovine subjectification which take effect as part of establishing robotic milking on farms' need to be taken into consideration [18].

These authors consider, after their observations, that 'instead of focussing on exceptional 'good' cows, [farmers] are directed by the robot to concentrate on exceptional 'bad' ones. 'Far from simply granting animals their freedom' they consider 'cows are re-enclosed by a set of power relations and corporeal and behavioural interventions associated with this particular technology' [18]. Clearly that paper is one set of authors' views indeed those of social scientists rather than biolgists or agriculturalists, so the lack of finding of stress-related physiological changes in cattle milked in an AMS system may be more relevant to an assessment of their welfare in robotic milking systems, but nonetheless it is worth taking on board their opinions with regard to how automatic milking systems impact on cattle health and welfare.

\section{References}

1. Fraser D (2008) Understanding animal welfare. Acta Veterinaria Scandinavica 50(1): S1.

2. Oltenacu PA, Broom DM (2010) The impact of genetic selection for increased milk yield on the welfare of dairy cows. Animal Welfare, 19(1): 39-49.

3. Von Keyserlingk MA, Rushen J, de Passillé AM, Weary DM (2009) Invited review: The welfare of dairy cattle-Key concepts and the role of science. Journal of Dairy Science 92(9): 4101-4111.
4. O’Rourke D (2009) Nutrition and udder health in dairy cows: a review. Irish Veterinary Journal 62(4): S15-20.

5. Jamali H, Barkema HW, Jacques M, Lavallée-Bourget EM, Malouin F, et al. (2018) Invited review: Incidence, risk factors, and effects of clinical mastitis recurrence in dairy cows. Journal of Dairy Science 101: 47294746.

6. O'Callaghan K (2002) Lamneness and associated pain in cattlechallenging traditional perceptions. In Practice 24(4): 212.

7. De Vries A (2017) Economic trade-offs between genetic improvement and longevity in dairy cattle. Journal of Dairy Science 100(5): 41844192.

8. Bugueiro A, Fouz R, Camino F, Yus E, Diéguez FJ (2018) Robot milking and relationship with culling rate in dairy cows. animal. Animal 29: 1-7.

9. Hovinen M, Pyörälä S (2011) Invited review: Udder health of dairy cows in automatic milking. Journal of dairy science 94(2): 547-562.

10. Castro A, Pereira JM, Amiama C, Bueno J (2015) Mastitis diagnosis in ten Galician dairy herds (NW Spain) with automatic milking systems. Spanish Journal of Agricultural Research 13(4): 0504.

11. Land A, Van Lenteren AC, Schooten EV, Bouwmans C, Gravesteyn DJ, et al. (2000) Effects of husbandry systems on the efficiency and optimisation of robotic milking performance and management. In Robotic milking: Proceedings of the International Symposium pp. 167-176.

12. Klaas IC, Rousing T, Fossing C, Hindhede J, Sorensen JT (2003) Is lameness a welfare problem in dairy farms with automatic milking systems? Animal Welfare 12(4): 599-604.

13. Pastell M, Kujala M, Aisla AM, Hautala M, Poikalainen V, et al. (2008) Detecting cow's lameness using force sensors. Computers and Electronics in Agriculture 64(1): 34-38.

14. Pastell M, Hänninen L, De Passillé AM, Rushen J (2010) Measures of weight distribution of dairy cows to detect lameness and the presence of hoof lesions. Journal of Dairy Science 93(3): 954-960.

15. Kruip TA, Stefanowska J, Ouweltjes W (2000) Robot milking and effect on reproduction in dairy cows: a preliminary study. Animal Reproduction Science 60: 443-447.

16. Weiss D, Helmreich S, Mostl E, Dzidic A, Bruckmaier RM (2004) Coping capacity of dairy cows during the change from conventional to automatic milking. Journal of Animal Science 82(2): 563-570.

17. Hopster HR, Bruckmaier RM, Vander Werf JT, Korte SM, Macuhova J, et al. (2002) Stress responses during milking; comparing conventional and automatic milking in primiparous dairy cows. Journal of Dairy Science 85(12): 3206-3216.

18. Holloway L, Bear C, Wilkinson K (2014) Re-capturing bovine life: Robot-cow relationships, freedom and control in dairy farming. Journal of Rural Studies 33: 131-140. 
(c) (1)

This work is licensed under Creative Commons Attribution 4.0 License

DOI: 10.19080/JDVS.2019.09.555772
Your next submission with Juniper Publishers will reach you the below assets

- Quality Editorial service

- Swift Peer Review

- Reprints availability

- E-prints Service

- Manuscript Podcast for convenient understanding

- Global attainment for your research

- Manuscript accessibility in different formats

( Pdf, E-pub, Full Text, Audio)

- Unceasing customer service

Track the below URL for one-step submission https://juniperpublishers.com/online-submission.php 